\title{
L'Idea di lavoro presso i Greci della Calabria medioevale
}

Filippo Burgarella

\section{(2) OpenEdition}

\section{Journals}

Edizione digitale

URL: http://journals.openedition.org/etudesbalkaniques/367

ISSN: 2102-5525

Editore

Association Pierre Belon

\section{Edizione cartacea}

Data di pubblicazione: 1 gennaio 1995

Paginazione: 53-70

ISBN: 2-910860-01-9

ISSN: $1260-2116$

\section{Notizia bibliografica digitale}

Filippo Burgarella, «L'Idea di lavoro presso i Greci della Calabria medioevale », Études balkaniques [En ligne], 2 | 1995, mis en ligne le 08 avril 2009, consulté le 02 mai 2019. URL : http:// journals.openedition.org/etudesbalkaniques/367

Questo documento è stato generato automaticamente il 2 maggio 2019.

Tous droits réservés 


\section{L'Idea di lavoro presso i Greci della Calabria medioevale}

Filippo Burgarella

\section{AUTORE}

FILIPPO BURGARELLA

Professeur - Università degli Studi della Calbria, Cosenza 